\title{
Preeclampsia and toxic metals: a case- control study in Kinshasa, DR Congo
}

\author{
Jean-Pierre Elongi Moyene ${ }^{1,7^{*}+}$, Hans Scheers ${ }^{2 \dagger}$, Barthélémy Tandu-Umba ${ }^{1}$, Vincent Haufroid ${ }^{3}$, \\ Baudouin Buassa-bu-Tsumbu', Fons Verdonck ${ }^{4}$, Bernard Spitz ${ }^{5,6}$ and Benoit Nemery ${ }^{2}$
}

\begin{abstract}
Background: Preeclampsia is frequent in Kinshasa (Democratic Republic of Congo), especially during the dry season. We tested whether preeclampsia was associated with exposure to environmental metals.

Methods: Using a case-control design, 88 women hospitalized with preeclampsia (cases) and 88 healthy pregnant women from the antenatal clinic (controls) were included in the study; 67 and 109 women were enrolled during the rainy and dry season, respectively. The concentrations of 24 elements were quantified by inductively coupled plasma mass spectrometry (ICP-MS) in 24-h urine collections. Differences in the urinary excretion of metals were investigated between cases and controls, and the interaction with season was assessed.

Results: Cases and controls were well matched regarding age, parity and duration of pregnancy. In controls, the urinary concentrations of most elements were substantially higher than reference values for adults from industrially developed countries, e.g. for lead: geometric mean (GM) $8.0 \mu \mathrm{g} / \mathrm{L}\left[25^{\text {th }}-75^{\text {th }}\right.$ percentile $\left.3.1-13.8\right]$. The daily urinary excretions of 14 metals were significantly higher in women with preeclampsia than in control women, e.g. for lead: GM $61 \mu \mathrm{g} /$ day $\left(25^{\text {th }}-75^{\text {th }}\right.$ percentile $\left.8-345\right)$ in women with preeclampsia vs $9 \mu \mathrm{g} /$ day $\left(25^{\text {th }}-75^{\text {th }}\right.$ percentile $\left.3-21\right)$ in controls $(p<0$ 001). A significant interaction was found between season and preeclampsia for several elements, with higher urinary excretions in preeclamptic women than controls during the dry season, but not during the rainy season.
\end{abstract}

Conclusions: This study revealed not only that women with preeclampsia excrete higher amounts of several toxic metals, especially lead, than control women, but also that this excretion exhibits seasonal variation, thus possibly explaining the high incidence and seasonal variation of preeclampsia in Kinshasa. Although the exact sources of this exposure are unknown, these findings underscore the need for preventing environmental exposures to lead and other toxic metals.

Keywords: Metal pollution, Lead, Preeclampsia, Hypertension, Seasonality, Developing country, Global health

\section{Background}

Preeclampsia is a leading cause of maternal and perinatal deaths, especially in poor countries [1]. With almost 10 million inhabitants, Kinshasa, the capital of the Democratic Republic of Congo, is the second most populated urban area of sub-Saharan Africa. Not only is the incidence of preeclampsia high in Kinshasa, its frequency

\footnotetext{
* Correspondence: elongi2002@yahoo.fr

${ }^{\dagger}$ Equal contributors

'Department of Gynecology and Obstetrics, University of Kinshasa, and General Hospital of Kinshasa, Kinshasa, Democratic Republic of Congo

${ }^{7}$ Hôpital Général de Kinshasa, Avenue de l'Hôpital, Commune de la Gombe, Kinshasa, DR, Congo

Full list of author information is available at the end of the article
}

also exhibits a striking seasonal variation: a retrospective study of more than 17,500 pregnancies between 2003 and 2007 showed prevalences of preeclampsia of $6 \%$ during the rainy season and $13 \%$ in the dry season [2].

The causes for the high incidence and seasonal variation of preeclampsia in Kinshasa are not known. Since a low intake of dietary anti-oxidants contributes to preeclampsia [3], it is possible that the risk of preeclampsia increases in the dry season because of a lower availability of fresh vegetables. Although some evidence supports the latter mechanism [4], another complementary explanation is that exposure to pro-oxidant metals plays a role. Preeclampsia has been associated with exposure to 
metals, such as lead [5], and a high degree of pollution by trace metals has been shown in Kinshasa [6]. The extent and sources of this pollution are not well known, but like many other megacities in low-to-middle income countries, Kinshasa suffers from considerable air, soil and water pollution, as a result of heavy traffic (with many old cars and resuspension of road dust), smoke from burning biomass and refuse, road and building works, unregulated activity of lots of small enterprises and workshops (welding, battery recycling, ...) in residential areas, etc. Studies in US children have documented that the uptake of lead increases during the dry season because of resuspension of lead-contaminated soil dust [7].

The objectives of the present case-control study were to determine whether women with preeclampsia had evidence of a higher exposure to trace metals than control pregnant women, and whether this was more the case in the dry season than in the wet season.

\section{Methods}

\section{Study design and setting}

In a case-control study design, we compared the 24-h urinary excretion of metals and metalloids in pregnant women suffering from preeclampsia or eclampsia (cases) with that of healthy pregnant women (controls).

The study was conducted at the General Hospital of Kinshasa, the largest hospital in the Democratic Republic of Congo. Data were collected during two periods with different meteorological characteristics: the rainy season (inclusions between 1 March and 18 April 2011) and the dry season (inclusions between 1 July and 2 September 2011).

\section{Participants}

All participants were pregnant women having had at least one prior pregnancy (i.e. nulliparous women were not included). Women with preeclampsia were inpatients recruited from the hospital's obstetric ward or intensive care unit. Preeclampsia was defined, according to current diagnostic criteria of the National High Blood Pressure Education Program [8], as the occurrence, in the second or third trimester of pregnancy, of hypertension (systolic blood pressure $>140 \mathrm{~mm} \mathrm{Hg}$ and diastolic blood pressure $>90 \mathrm{~mm} \mathrm{Hg}$ after at least 15 min of rest), combined with proteinuria (positive dipstick test or $>$ $300 \mathrm{mg}$ proteins $/ 24 \mathrm{~h}$ ), with or without oedema. Eclampsia was defined as the occurrence of seizures in a pregnant woman presenting the above criteria, in the absence of neurological disease or brain injury. Concurrent control subjects were selected from the outpatient antenatal care unit of the same hospital so as to match patients in terms of age, gestational age, type of pregnancy (single or multiple), and number of live-born children. Subjects with chronic and debilitating disease, smokers, and regular consumers of alcohol were not included. All selected subjects were informed about the purpose and procedures of the study. Participation in the study was voluntary and there were no refusals to participate among eligible patients with pre-eclampsia. Controls were offered 1,000 francs (about 1 US dollar) to cover transport costs and only few refused to participate: four control women declined to participate because they found 1,000 francs insufficient to cover their travel expenses; two control women who had accepted and received 1,000 francs did not report back. These controls were replaced by other women.

The final protocol was approved by the ethical committee of the National Order of Physicians of the DR Congo (COM/013/HPGRK/2011).

\section{Variables}

Medical history (including hypertension and diabetes) and obstetrical history were obtained from the patient's clinical notes. Height and weight were measured to calculate body mass index (BMI). A questionnaire, elaborated in house and consisting of simple questions in French or Lingala, was administered face-to-face by various interviewers to cases and controls to assess educational level (illiterate; elementary or secondary school; higher education), annual income (low, intermediate or high), occupation (paid work outside the home or not), cooking mode (biomass fuel, gas, electricity), geophagy (the consumption of clay, a frequent habit among pregnant women in Africa [9]) and specific activities with possible metal pollution close to the residence (recycling of batteries, spray painting, or welding). Area of residence was registered as one of the 24 "communes" in the Kinshasa agglomeration.

In hospitalized patients with preeclampsia, urine was collected by vesical catheterization, starting at admission; the catheter was inserted without use of a lubricating agent and $24 \mathrm{~h}$ urine was collected in a sterile graduated plastic container. Control subjects received a plastic vessel (with a large opening and closely fitting lid) and they were instructed to void their urine directly into the vessel without external contamination during a set period of $24 \mathrm{~h}$, and to bring the containers back to the hospital as soon as the collection was finished.

After recording total volume, approximately $20 \mathrm{~mL}$ urine were transferred into polystyrene containers with screw caps (Plastiques-Gosselin, Hazebrouck, France), which were kept frozen and then transported (in three batches) in isothermal boxes to Belgium by commercial flights.

\section{Measurements}

As in previous publications $[10,11]$, the urinary concentrations of 24 metals and metalloids [lithium (Li), beryllium $(\mathrm{Be})$, aluminium $(\mathrm{Al})$, vanadium $(\mathrm{V})$, chromium 
$(\mathrm{Cr})$, manganese $(\mathrm{Mn})$, cobalt $(\mathrm{Co})$, nickel $(\mathrm{Ni})$, copper $(\mathrm{Cu})$, zinc $(\mathrm{Zn})$, arsenic $(\mathrm{As})$, selenium $(\mathrm{Se})$, molybdenum (Mo), cadmium (Cd), indium (In), tin (Sn), antimony $(\mathrm{Sb})$, tellurium $(\mathrm{Te})$, barium $(\mathrm{Ba})$, platinum $(\mathrm{Pt})$, thallium $(\mathrm{Tl})$, lead $(\mathrm{Pb})$, bismuth $(\mathrm{Bi})$, and uranium $(\mathrm{U})$, all called "metals" hereafter] were simultaneously measured by inductively coupled argon plasma mass spectrometry (ICP-MS), using validated and ISO15189 certified procedures, with quality control/quality assurance procedures, as described in the additional files. Four metals (Be, In, $\mathrm{Pt}$, and $\mathrm{Bi}$ ) were not considered further because more than half of the samples had concentrations below the limit of detection (LOD). Creatinine was determined by a modified Jaffe reaction using an Olympus AU2700 analyzer (Olympus, Hamburg, Germany).

\section{Data presentation and statistical analysis}

Data management and statistical analysis were performed in SAS 9.3 (SAS Institute, Cary, USA). Except for $\mathrm{Be}, \mathrm{In}, \mathrm{Pt}$ and $\mathrm{Bi}$, only few measurements were below the LOD; these values were assigned a value at half the LOD. Urinary metal concentrations $(\mu \mathrm{g} / \mathrm{L})$ were multiplied by the daily urine volume (L/day) to obtain the total amount of metal excreted per $24 \mathrm{~h}(\mu \mathrm{g} /$ day). Metal concentrations $(\mu \mathrm{g} / \mathrm{L})$ and daily metal excretions $(\mu \mathrm{g} /$ day $)$ were not normally distributed, but all sets of values met the assumption of normal distribution after logtransformation. Data are reported as geometric means with $25^{\text {th }}$ and $75^{\text {th }}$ percentiles. Two-way ANOVA, followed by Tukey's post hoc tests, were performed to disentangle the separate and joint effects of preeclampsia and season. Categorical variables were evaluated by chi square tests or Fisher exact tests, and interpreted as odds ratios (OR) with $95 \%$ confidence intervals (CI). To compare the geographical distribution between cases and controls, communes were pooled in five zones, largely corresponding with the four districts of Kinshasa (Fig. 1). A correlation analysis between the metal excretion values was performed and this was followed by a principal component analysis (PCA) to derive a composite metal excretion variable. The significance level was set at $p<0.05$. The Benjamini-Hochberg method [12] to reduce the risk of type I errors when making multiple comparisons, was used but this did not modify the conclusions obtained without applying such correction, and the $p$ values shown are those obtained without correcting for multiple testing.

\section{Results}

A total of 178 pregnant women were enrolled, equally divided among the preeclamptic and control groups. For one control woman and one preeclamptic woman, no urine data were available due to damaged containers. Thus, data from 88 women with preeclampsia (34 included during the rainy season and 54 during the dry season) and 88 controls (33 included during the rainy season and 55 during the dry season) were available for analysis.

The matching strategy led to the case and control groups being highly similar except, of course, for blood pressure (Table 1). In each group, seven women had a twin pregnancy. In regard to environmental factors (Table 2), cases and controls did not differ with regard to residential location, cooking mode and prevalence of geophagy. However, artisanal activities close to home (such as recycling of batteries, spray painting and welding) tended to be more frequently reported in the preeclamptic group $(p=0.064)$. Pooling these activities into a single category gave a significant association with preeclampsia (OR $=2.34,95 \%$ CI 1.13-4.85, $p=0.02$ ).

A large proportion of samples collected in the dry season turned out to have unreliably low concentrations of creatinine $(<0.3 \mathrm{~g} / \mathrm{L})$, probably because one batch had remained unfrozen during transportation or before.

Detailed figures for the metal concentrations found in the control women are given for reference in additional files (Additional file 1: Tables S1-S3). For many metals, the values were substantially higher than reference values found in other populations of non-pregnant adults from the USA [13, 14] or Belgium [15]. Urinary concentrations of all metals, except $\mathrm{Li}$, were significantly higher in preeclamptic subjects than in controls (Table 3). The highest contrasts between the two groups were observed for $\mathrm{Zn}, \mathrm{Sn}$ and $\mathrm{Pb}$ with approximately 9fold differences in geometric means.

When metal concentrations were expressed per gram creatinine, the values remained significantly higher in the preeclamptic group for all but four metals $(\mathrm{Li}, \mathrm{Mo}, \mathrm{V}$, and Tl) (Additional file 1: Table S4). However, sample size was considerably smaller for the creatinine-corrected analysis ( $N=59$ and $N=63$ for the rainy season and dry season, respectively), because many urine samples with too low creatinine $(<0.3 \mathrm{~g} / \mathrm{L})$ had to be excluded.

Nevertheless, collection of total urine production in $24 \mathrm{~h}$ allowed us to calculate the daily amount of metals excreted in urine $(\mu \mathrm{g} /$ day). Diuresis itself differed markedly between the two study groups: on average, women with preeclampsia produced $275 \mathrm{~mL}(23 \%)$ less urine in $24 \mathrm{~h}$ than control women (Table 4). Using the amount of metals excreted per day, the groups no longer differed for $\mathrm{V}, \mathrm{As}, \mathrm{Se}, \mathrm{Mo}$ and $\mathrm{Tl}$, in addition to $\mathrm{Li}$, but the daily excretion of 13 elements remained significantly higher in preeclamptic women than in controls, by less than two-fold for $\mathrm{Al}, \mathrm{Te}$, and $\mathrm{U}$, by 2- to 5 -fold for $\mathrm{Cr}, \mathrm{Mn}, \mathrm{Co}, \mathrm{Ni}, \mathrm{Cu}, \mathrm{Cd}$, and $\mathrm{Sb}$, and by 6- to 7 fold for $\mathrm{Zn}, \mathrm{Sn}$, and $\mathrm{Pb}$ (Table 4).

Within the group of preeclamptic patients, there were three women with eclampsia in each season. These six 


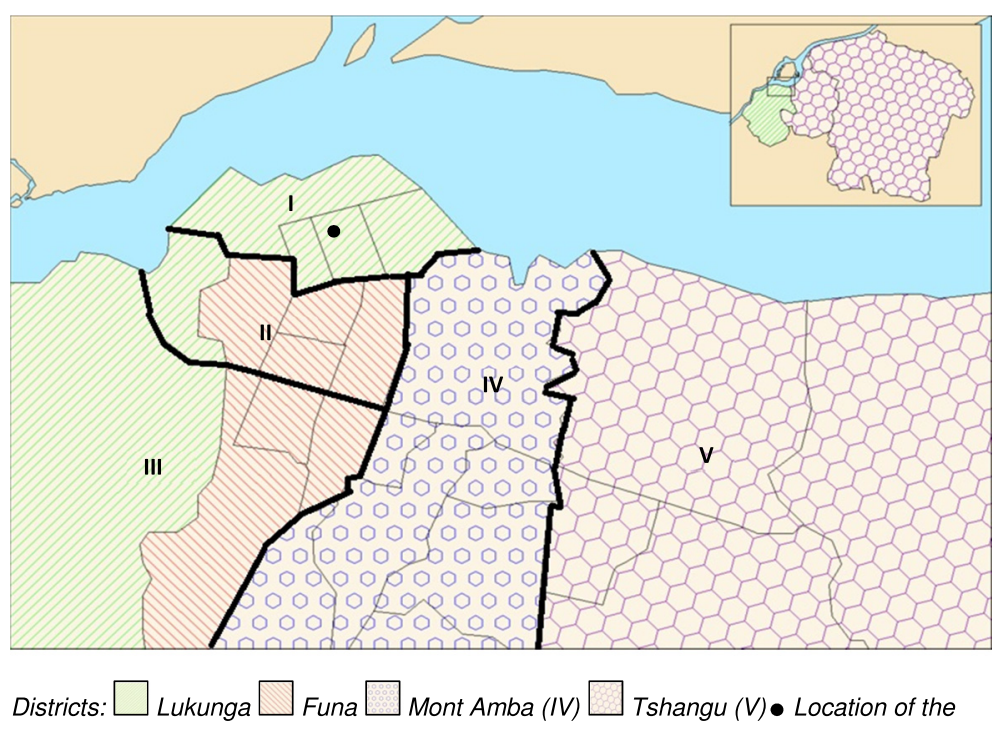

General Hospital within the commune of Kinshasa (district Lukunga)

I - V: geographical zones, as constructed here for statistical purposes. Zone I contains the historical center and business district of Kinshasa.

Fig. 1 Map of Kinshasa with administrative entities and location of the General Hospital. I - V: geographical zones, as constructed here for statistical purposes. Zone I contains the historical center and business district of Kinshasa

Table 1 Personal characteristics of women with or without preeclampsia

\begin{tabular}{lll}
\hline & Control $(N=88)$ & Preeclamptic (N=88) \\
\hline Age (years) & $26 \cdot 7 \pm 5 \cdot 9$ & $27 \cdot 1 \pm 6 \cdot 1$ \\
Height $(\mathrm{m})$ & $1 \cdot 62 \pm 0 \cdot 07$ & $1 \cdot 62 \pm 0 \cdot 09$ \\
Weight $(\mathrm{kg})$ & $73 \cdot 5 \pm 8 \cdot 8$ & $73 \cdot 6 \pm 9 \cdot 8$ \\
BMl $\left(\mathrm{kg} / \mathrm{m}^{2}\right)$ & $27 \cdot 9 \pm 3 \cdot 0$ & $28 \cdot 1 \pm 3 \cdot 7$ \\
Blood pressure (mm Hg) & & \\
Systolic & $112 \pm 12$ & $186 \pm 25$ \\
Diastolic & $72 \pm 10$ & $119 \pm 23$ \\
Gestational age (weeks) & $36 \cdot 2 \pm 2 \cdot 2$ & $36 \cdot 8 \pm 2 \cdot 1$ \\
Parity & & \\
1 & $36(41 \%)$ & $44(50 \%)$ \\
2 & $21(24 \%)$ & $18(20 \%)$ \\
3 & $19(22 \%)$ & $15(17 \%)$ \\
$3+$ & $12(14 \%)$ & $11(13 \%)$ \\
Education level & & $45 \%)$ \\
1 illiterate & $2(2 \%)$ & $9(10 \%)$ \\
2 elementary school & $75(85 \%)$ & \\
3 secondary school & $11(13 \%)$ & \\
\hline
\end{tabular}

Data are arithmetic means \pm SD, or counts (\%) women did not differ from the other women with preeclampsia with regard to personal characteristics and urinary metal values (data not shown). Therefore, no further differentiation was made between results for preeclamptic and eclamptic patients.

For 10 out of 20 elements, urinary concentrations (Additional file 1: Table S5) and daily excretions (Table 5) differed significantly between seasons, always being higher in the rainy season than in the dry season (regardless of the case or control status). Since the volume of urine was not affected by season, qualitatively similar seasonal effects were found for urinary concentrations and daily excretion. Preeclamptic women had significantly higher daily metal excretion than control women for 16 elements in the dry season, but for only five elements in the rainy season. Interactions between season and preeclampsia were significant for $\mathrm{Li}, \mathrm{As}, \mathrm{Se}, \mathrm{Sb}, \mathrm{Te}$, $\mathrm{Tl}$ and $\mathrm{Pb}$. Figure 2 illustrates that $\mathrm{Pb}$ excretion was 11.6-fold higher among preeclamptic women than control women in the dry season, but only 2.7 -fold higher in the rainy season.

The daily excreted quantities of metals were highly correlated among each other, except for $\mathrm{Li}$ and Mo (Additional file 1: Table S6). The subsequent PCA revealed that the eigenvalue of the first PC accounted for $43 \%$ of the total variance, and three eigenvalues explained $67 \%$ of the total variance. The first PC was positively correlated with all 20 metals (all $p<0.001$ ), indicating that this $\mathrm{PC}$ can be considered as a composite 
Table 2 Environmental characteristics of women with or without preeclampsia

\begin{tabular}{|c|c|c|c|}
\hline & Control $(N=88)$ & $\begin{array}{l}\text { Preeclamptic } \\
(N=88)\end{array}$ & $P^{\#}$ \\
\hline Residence (zone) ${ }^{a}$ & & & $0 \cdot 22$ \\
\hline । & $20(23 \%)$ & $16(18 \%)$ & \\
\hline$\|$ & $17(20 \%)$ & $15(17 \%)$ & \\
\hline III & $11(13 \%)$ & $14(16 \%)$ & \\
\hline IV & $29(33 \%)$ & $22(25 \%)$ & \\
\hline V & $10(11 \%)$ & $21(24 \%)$ & \\
\hline Occupation & & & 0.049 \\
\hline 0 no paid work & $33(38 \%)$ & $46(52 \%)$ & \\
\hline 1 paid work & $55(62 \%)$ & $42(48 \%)$ & \\
\hline Reported cooking mode & & & $0 \cdot 13$ \\
\hline 1 biomass fuel & $13(15 \%)$ & $21(24 \%)$ & \\
\hline 2 gas or electricity & $75(85 \%)$ & $67(76 \%)$ & \\
\hline Reported geophagy & & & 0.62 \\
\hline 0 no & $64(73 \%)$ & $60(68 \%)$ & \\
\hline 1 yes & $24(27 \%)$ & $28(32 \%)$ & \\
\hline \multicolumn{4}{|c|}{ Reported activities in vicinity } \\
\hline spray painting & $1(1 \%)$ & $7(8 \%)$ & $0 \cdot 06$ \\
\hline welding & $5(6 \%)$ & $8(9 \%)$ & \\
\hline battery recycling & $8(9 \%)$ & $12(14 \%)$ & $0.02^{\dagger}$ \\
\hline none of these & $74(84 \%)$ & $61(69 \%)$ & \\
\hline
\end{tabular}

Data are counts (\%)

${ }^{\#} P$-values for chi square or Fisher exact tests on frequencies. ${ }^{a} Z$ Zones as defined in Fig. $1 .{ }^{\dagger} P$-value for an additional chi square test with spray painting, welding and battery recycling pooled vs no activities

metal excretion variable. A two-way ANOVA, similar to those performed for the individual elements, resulted in a highly significant group effect $(p<0.001)$ with higher values for preeclamptics than for control subjects, a highly significant season effect $(p<0.001)$ with higher values during the rainy season, and a significant interaction effect $(p=0.038)$, revealing that the higher values in patients occurred in the dry season and not in the rainy season.

\section{Discussion}

We demonstrated a very high exposure to pollutant metals in pregnant women in Kinshasa, and observed that women with preeclampsia excreted higher quantities of metals than pregnant women without preeclampsia. Moreover, the differences in metal excretion between the two groups were less pronounced in the rainy season than in the dry season, when the incidence of preeclampsia is highest.

We studied a relatively large group of women hospitalized for preeclampsia, who were compared with an equal number of well-matched healthy pregnant women without preeclampsia. Novel features of our study include the use of ICP-MS (allowing the measurement of several elements in one sample), the collection of 24-h urine (thus avoiding the need for correcting for urine dilution), and the enrolment over two different seasons in order to understand the seasonality of preeclampsia.

An obvious limitation of our study is its case-control design and the absence of measurements before (or after) the third trimester of pregnancy, which precludes drawing causal inferences. Other limitations are the absence of blood measurements, and the lack of dietary or environmental exposure data.

One could criticize that our control group did not necessarily reflect the source population of our cases, since it consisted of healthy pregnant women recruited from an antenatal clinic, rather than pregnant women hospitalized for reasons other than preeclampsia (e.g. malaria, diabetes, or hypertension without proteinuria). However, our control subjects came from the same geographical areas as the cases, and they were closely matched for important factors such as age, parity and gestational age. So, our control group may be considered a suitable group of community controls from the city of Kinshasa. From a methodological point, a relative limitation is that we did not perform a matched analysis of the data, even though our controls had been selected by individual matching with cases. Whilst this may have led to a bias towards the null for some metals, it does not affect our overall conclusions.

Another limitation is that our study was conducted in non-nulliparous women. A first pregnancy is a major risk factor for the occurrence of preeclampsia [3] and we wanted to avoid this dominant risk factor in order to increase the chances of detecting associations with other, possibly less influential environmental factors. The exclusion of nulliparous women limits the generalizability of our findings and further studies should be conducted to verify whether our observations also apply to primigravidae.

The average concentrations of metals or metalloids found in the urine of our control subjects were substantially higher than the upper limits published for adults from the general population in economically developed countries [13-15]. The high values found here corroborate findings previously reported for the general population of Kinshasa [6].

One caveat is that pregnancy itself may affect the urinary excretion of metals. Thus, $\mathrm{Pb}$ is well-known to be mobilized from its skeletal stores during pregnancy [16]. After an initial decrease during early pregnancy, blood $\mathrm{Pb}$ levels increase moderately during the third trimester of pregnancy, especially in older women and if calcium intake levels are low $[17,18]$. A daily excretion of 0.8 to $5.9 \mu \mathrm{g} \mathrm{Pb}$ (geometric mean of $1.9 \mu \mathrm{g}$; compared with $9.1 \mu \mathrm{g}$ in our control group) was found during pregnancy and post-partum in 13 Australian women [19]. 
Table 3 Urinary metal concentrations (in $\mu \mathrm{g} / \mathrm{L}$ ) in pregnant women with or without preeclampsia in Kinshasa

\begin{tabular}{|c|c|c|c|c|c|c|}
\hline & Control $(N=88)$ & Preeclamptic $(N=88)$ & Fold difference & $P^{\#}$ & $\begin{array}{l}\text { Upper reference limit } \\
\text { NHANES }^{+}\end{array}$ & $\begin{array}{l}\text { Upper reference limit } \\
\text { Belgium }\end{array}$ \\
\hline $\mathrm{Li}$ & $6 \cdot 30(3 \cdot 34-11 \cdot 8)$ & $7 \cdot 02(4 \cdot 77-9 \cdot 53)$ & $1 \cdot 1$ & $0 \cdot 30$ & & 100 \\
\hline $\mathrm{Al}$ & $55 \cdot 4(21 \cdot 9-172)$ & $132(48 \cdot 5-400)$ & $2 \cdot 4$ & $<0.001$ & $34 \cdot 0^{\mathrm{b}}$ & 15 \\
\hline V & $1 \cdot 44(0 \cdot 97-1 \cdot 90)$ & $2 \cdot 09(1 \cdot 21-3 \cdot 49)$ & $1 \cdot 5$ & $<0 \cdot 001$ & & $1 \cdot 5$ \\
\hline $\mathrm{Cr}$ & $0 \cdot 88(0 \cdot 39-2 \cdot 46)$ & $4 \cdot 57(1 \cdot 02-24 \cdot 3)$ & $5 \cdot 2$ & $<0 \cdot 001$ & $0 \cdot 48^{\mathrm{a}}, 3 \cdot 5^{\mathrm{b}}$ & $0 \cdot 55$ \\
\hline$M n$ & $9 \cdot 20(2 \cdot 06-27 \cdot 7)$ & $44 \cdot 5(5 \cdot 32-273)$ & $4 \cdot 8$ & $<0 \cdot 001$ & $2 \cdot 71^{\mathrm{a}}$ & 0.75 \\
\hline Co & $0 \cdot 54(0 \cdot 21-1 \cdot 37)$ & $2 \cdot 07(0 \cdot 75-4 \cdot 19)$ & $3 \cdot 9$ & $<0.001$ & $4 \cdot 69^{a}, 1 \cdot 8^{b}$ & $1 \cdot 8$ \\
\hline $\mathrm{Ni}$ & $4 \cdot 14(2 \cdot 42-8 \cdot 98)$ & $13 \cdot 8(6 \cdot 3-25 \cdot 1)$ & $3 \cdot 3$ & $<0 \cdot 001$ & $12 \cdot 0^{b}$ & 6 \\
\hline $\mathrm{Cu}$ & $34 \cdot 4(10 \cdot 6-134)$ & $226(69.5-562)$ & $6 \cdot 6$ & $<0 \cdot 001$ & $55 \cdot 0^{b}$ & 27 \\
\hline $\mathrm{Zn}$ & $627(186-1,129)$ & $5,863(1,229-40,950)$ & $9 \cdot 3$ & $<0 \cdot 001$ & $766 \cdot 8^{b}$ & 1620 \\
\hline As & $26 \cdot 8(13 \cdot 4-51 \cdot 6)$ & $46 \cdot 9(26 \cdot 1-79 \cdot 9)$ & $1 \cdot 7$ & $<0.001$ & $52 \cdot 2^{\mathrm{b}}$ & 300 \\
\hline Se & $27 \cdot 2(13 \cdot 5-54 \cdot 3)$ & $44 \cdot 6(24 \cdot 0-71 \cdot 8)$ & $1 \cdot 6$ & $<0 \cdot 001$ & $182 \cdot 0^{b}$ & 80 \\
\hline Mo & $13 \cdot 3(7 \cdot 2-29 \cdot 8)$ & $19 \cdot 2(10 \cdot 7-35 \cdot 6)$ & $1 \cdot 4$ & 0.023 & $128 \cdot 0^{a}, 66 \cdot 9^{b}$ & 150 \\
\hline $\mathrm{Cd}$ & $0.53(0 \cdot 29-0 \cdot 68)$ & $1 \cdot 78(0 \cdot 71-3 \cdot 85)$ & $3 \cdot 3$ & $<0.001$ & $1 \cdot 0^{b}$ & $1 \cdot 5$ \\
\hline Sn & $1 \cdot 25(0 \cdot 43-2 \cdot 60)$ & $10 \cdot 8(2 \cdot 2-48 \cdot 6)$ & $8 \cdot 7$ & $<0 \cdot 001$ & $34 \cdot 9^{b}$ & 4 \\
\hline $\mathrm{Sb}$ & $0 \cdot 46(0 \cdot 14-1 \cdot 57)$ & $1 \cdot 95(0 \cdot 84-4 \cdot 85)$ & $4 \cdot 2$ & $<0.001$ & $4 \cdot 17^{\mathrm{a}},<\mathrm{LOD}^{\mathrm{b}}$ & $0 \cdot 35$ \\
\hline $\mathrm{Te}$ & $0 \cdot 11(0 \cdot 07-0 \cdot 19)$ & $0 \cdot 23(0 \cdot 12-0 \cdot 26)$ & $2 \cdot 1$ & $<0.001$ & $<\mathrm{LOD}^{\mathrm{b}}$ & $0 \cdot 4$ \\
\hline $\mathrm{Ba}$ & $11 \cdot 7(5 \cdot 5-24 \cdot 9)$ & $34 \cdot 8(8 \cdot 4-123 \cdot 8)$ & $3 \cdot 0$ & $<0 \cdot 001$ & $5 \cdot 27^{\mathrm{a}}, 7 \cdot 0^{\mathrm{b}}$ & 9 \\
\hline $\mathrm{Tl}$ & $0 \cdot 23(0 \cdot 15-0 \cdot 45)$ & $0 \cdot 36(0 \cdot 24-0 \cdot 57)$ & $1 \cdot 6$ & $<0.001$ & $1 \cdot 18^{\mathrm{a}},<\mathrm{LOD}^{\mathrm{b}}$ & 0.6 \\
\hline $\mathrm{Pb}$ & $7 \cdot 98(3 \cdot 14-13 \cdot 8)$ & $71 \cdot 5(8 \cdot 89-398)$ & $9 \cdot 0$ & $<0 \cdot 001$ & $4 \cdot 93^{\mathrm{a}}, 4 \cdot 0^{\mathrm{b}}$ & 4 \\
\hline U & $0.04(0 \cdot 02-0 \cdot 09)$ & $0.08(0 \cdot 04-0 \cdot 17)$ & $2 \cdot 0$ & $<0 \cdot 001$ & $<\mathrm{LOD}^{\mathrm{b}}$ & 0.05 \\
\hline
\end{tabular}

Data are geometric means $\left(25^{\text {th }}-75^{\text {th }}\right.$ percentile) of urinary concentrations in $\mu \mathrm{g} / \mathrm{L}$

\# $P$-values obtained by contrasting preeclamptic patients and controls in a one-way ANOVA on log-transformed values

${ }^{\dagger}$ Upper reference limit in $\mu \mathrm{g} / \mathrm{L}$ for the general US population according to NHANES (US National Health and Nutrition Examination Survey) as published by Paschal et al. [13] $\left({ }^{\mathrm{a}}, \mathrm{P} 90\right)$ and Komaromy-Hiller et al. [14] $\left({ }^{\mathrm{b}}, \mathrm{P} 87 \cdot 5\right)$

${ }^{\ddagger}$ Upper reference limit in $\mu \mathrm{g} / \mathrm{L}$ for the general Belgian population, data from Hoet et al. [15] (upper limit of $90 \%$ confidence interval of P97·5)

Pregnant women from Lagos, Nigeria, had two to threefold higher concentrations of $\mathrm{Pb}$ in blood and urine than nonpregnant women [20].

It is conceivable that pregnancy also affects the toxicokinetics of other metals besides $\mathrm{Pb}$. However, although the reproductive and developmental toxicity of metals has received considerable attention [21], we found no human studies that evaluated pregnancy-related changes in the excretion of metals other than $\mathrm{Pb}$ [22].

The urinary metal concentrations were very high in our control subjects, but they were even higher in women with preeclampsia. A well-known issue when metals or other agents are measured in urine is how to correct for dilution. Usually, this is achieved by relating the concentrations of the analyte to that of creatinine, because it is assumed that the daily excretion of creatinine is constant and reasonably equal for all (normal) subjects [22, 23]. However, the validity of creatinine corrections has not been established during pregnancy, let alone in preeclampsia. Moreover, creatinine may be degraded when samples are not kept cold, as probably happened with one of the batches of the present study. We, therefore, chose not to rely on creatinine-corrected values, even though the differences in metal concentrations between the two groups also held when creatinine corrections were applied (see Additional file 1: Table S4).

However, since urine had been collected over $24 \mathrm{~h}$, we were able to express our data in terms of daily excretion, which is probably the best option. As expected [24, 25], the women with preeclampsia produced substantially less urine than control women, thus reducing the differences between the two groups without, however, abolishing them. In the (hospitalized) women with preeclampsia, urine was collected via urinary catheter, whilst the control (outpatient) women collected their 24-h urine at home; the latter entails a risk of external contamination and of incomplete urine collections among controls, but both factors would tend to reduce (rather than spuriously create) the differences found in metal excretions between the two groups. Hence, the differences found between cases and controls are unlikely to be artifactual. Nevertheless, some of the increased metal concentrations in preeclamptic women may be due to proteinuria, since many metals are bound to serum proteins. We did not attempt to evaluate this with our material. 
Table 4 Daily urinary metal excretion (in $\mu \mathrm{g} /$ day) in pregnant women with or without preeclampsia in Kinshasa

\begin{tabular}{|c|c|c|c|c|c|}
\hline & Control $(N=88)$ & Preeclamptic $(N=88)$ & Fold diff. & $P^{\#}$ & $\begin{array}{l}\text { Upper reference limit } \\
\text { NHANES }^{a, b}\end{array}$ \\
\hline $24 \mathrm{~h}$ diuresis $(\mathrm{mL})$ & $1,182(925-1,415)$ & $907(695-1,100)$ & & $<0 \cdot 001$ & N/A \\
\hline $\mathrm{Li}$ & $7 \cdot 17(3 \cdot 68-13 \cdot 3)$ & $5 \cdot 98(3 \cdot 76-8 \cdot 56)$ & $0 \cdot 9$ & $0 \cdot 10$ & \\
\hline $\mathrm{Al}$ & $63 \cdot 0(21 \cdot 5-220)$ & $113(46-352)$ & $1 \cdot 8$ & $0 \cdot 009$ & $60 \cdot 8$ \\
\hline V & $1 \cdot 64(1 \cdot 00-2 \cdot 50)$ & $1 \cdot 78(1 \cdot 02-2 \cdot 99)$ & $1 \cdot 1$ & 0.43 & \\
\hline $\mathrm{Cr}$ & $1 \cdot 00(0 \cdot 37-3 \cdot 39)$ & $3 \cdot 89(0 \cdot 81-20 \cdot 1)$ & $3 \cdot 9$ & $<0 \cdot 001$ & $6 \cdot 7$ \\
\hline $\mathrm{Mn}$ & $10 \cdot 5(2 \cdot 38-29 \cdot 0)$ & $37 \cdot 9(4 \cdot 4-274)$ & $3 \cdot 6$ & $0 \cdot 001$ & \\
\hline Co & $0 \cdot 61(0 \cdot 24-1 \cdot 73)$ & $1 \cdot 76(0 \cdot 67-4 \cdot 01)$ & $2 \cdot 9$ & $<0 \cdot 001$ & \\
\hline $\mathrm{Ni}$ & $4 \cdot 71(2 \cdot 47-10 \cdot 2)$ & $11 \cdot 8(5 \cdot 29-20 \cdot 8)$ & $2 \cdot 5$ & $<0 \cdot 001$ & $10 \cdot 7$ \\
\hline $\mathrm{Cu}$ & $39 \cdot 2(11 \cdot 2-140 \cdot 1)$ & $193(64-530)$ & $4 \cdot 9$ & $<0 \cdot 001$ & $148 \cdot 0$ \\
\hline $\mathrm{Zn}$ & $714(194-1,074)$ & 4,993 (916-32,094) & $7 \cdot 0$ & $<0 \cdot 001$ & $1657 \cdot 5$ \\
\hline As & $30 \cdot 5(15 \cdot 0-59 \cdot 3)$ & $40 \cdot 0(23 \cdot 3-78 \cdot 7)$ & $1 \cdot 3$ & $0 \cdot 051$ & $70 \cdot 7$ \\
\hline Se & $31 \cdot 0(17 \cdot 8-63 \cdot 3)$ & $38 \cdot 0(20 \cdot 7-62 \cdot 4)$ & $1 \cdot 2$ & $0 \cdot 15$ & \\
\hline Mo & $15 \cdot 1(8 \cdot 0-33 \cdot 8)$ & $16 \cdot 3(7 \cdot 4-31 \cdot 1)$ & $1 \cdot 1$ & $0 \cdot 64$ & \\
\hline $\mathrm{Cd}$ & $0 \cdot 61(0 \cdot 32-0 \cdot 78)$ & $1 \cdot 51(0 \cdot 59-2 \cdot 73)$ & $2 \cdot 5$ & $<0 \cdot 001$ & $2 \cdot 1$ \\
\hline Sn & $1 \cdot 42(0 \cdot 51-3 \cdot 05)$ & $9 \cdot 22(1 \cdot 78-45 \cdot 6)$ & $6 \cdot 5$ & $<0 \cdot 001$ & \\
\hline $\mathrm{Sb}$ & $0 \cdot 52(0 \cdot 14-1 \cdot 66)$ & $1 \cdot 66(0 \cdot 62-5 \cdot 69)$ & $3 \cdot 2$ & $<0 \cdot 001$ & \\
\hline $\mathrm{Te}$ & $0 \cdot 12(0 \cdot 07-0 \cdot 21)$ & $0 \cdot 19(0 \cdot 09-0 \cdot 23)$ & $1 \cdot 6$ & $0 \cdot 018$ & \\
\hline $\mathrm{Ba}$ & $13 \cdot 3(5 \cdot 9-28 \cdot 9)$ & $29 \cdot 6(6 \cdot 6-93 \cdot 7)$ & $2 \cdot 2$ & $0 \cdot 001$ & \\
\hline $\mathrm{Tl}$ & $0 \cdot 26(0 \cdot 15-0 \cdot 50)$ & $0 \cdot 30(0 \cdot 20-0 \cdot 49)$ & $1 \cdot 2$ & $0 \cdot 22$ & $<\mathrm{LOD}$ \\
\hline $\mathrm{Pb}$ & $9 \cdot 09(3 \cdot 15-20 \cdot 5)$ & $60 \cdot 9(8 \cdot 3-345)$ & $6 \cdot 7$ & $<0 \cdot 001$ & $8 \cdot 0$ \\
\hline$U$ & $0.05(0 \cdot 02-0 \cdot 12)$ & $0.07(0 \cdot 03-0 \cdot 13)$ & $1 \cdot 5$ & 0.023 & \\
\hline
\end{tabular}

Data shown are geometric means $\left(25^{\text {th }}-75^{\text {th }}\right.$ percentile) of $24 \mathrm{~h}$ excreted quantities in $\mu \mathrm{g} / \mathrm{day}$

" $P$-values obtained by contrasting preeclamptic patients and controls in a one-way ANOVA on log-transformed values

a Upper reference limit in $\mu \mathrm{g} /$ day for the general US population according to NHANES, the US National Health and Nutrition Examination Survey, data from Komaromy-Hiller et al. [14] (P87-5)

${ }^{\mathrm{b}}$ No data expressed in $\mu \mathrm{g} /$ day are available for Belgium

The hypothesis that preeclampsia may be linked with $\mathrm{Pb}$ exposure already dates from the nineteenth century and it was verified by showing ecological associations between $\mathrm{Pb}$ in drinking water and the incidence of eclampsia in Britain in the early twentieth century [26]. In the USA, the risk of pregnancy-induced hypertension was shown to be associated with airborne lead concentrations averaged at state level [27]. A recent systematic review found a significant association between blood $\mathrm{Pb}$ and gestational hypertension or preeclampsia in six out of nine identified epidemiological studies [5]. Studies from Iran [28], Nigeria [29], and Egypt [30] also described higher blood $\mathrm{Pb}$ in preeclampsia. The simplest explanation for these findings is that the higher levels of $\mathrm{Pb}$ in blood (or in urine, as in our study) in women with preeclampsia, reflect a higher past or ongoing exposure to $\mathrm{Pb}$. Nevertheless, an alternative interpretation is that preeclampsia is accompanied by a higher release of $\mathrm{Pb}$ from body stores (or a higher leak through injured kidneys), than in normal pregnancy. Such possible "reverse causation" does not appear to have been investigated. In other words, like other cross-sectional studies, our study cannot tell whether (or to what extent) the much higher urinary (or indeed blood) $\mathrm{Pb}$ levels found in preeclamptic women indicate that $\mathrm{Pb}$ is involved in the pathogenesis of the disease or whether preeclampsia simply leads to higher levels of $\mathrm{Pb}$ in blood and urine. To solve the issue of causality would require assessing the incidence of preeclampsia in a longitudinal design. Observations made in the wake of the Hurricanes Katrina and Rita in New Orleans, argue against reverse causation because parallel changes occurred (at neighbourhood level) between soil concentrations of $\mathrm{Pb}$ and the incidence of eclampsia [31].

It is generally stated that blood $\mathrm{Pb}$ reflects body burden better than urine $\mathrm{Pb}$ [22]. However, this is valid in steady-state conditions only and probably not when $\mathrm{Pb}$ is being mobilized from bone, as in pregnancy. Thus, whilst measurements of blood $\mathrm{Pb}$ would have been desirable, 24-h excretion values are probably more relevant to assess differences in internal exposure to $\mathrm{Pb}$ between preeclampsia and normal pregnancy, whether this difference is due to a higher extraction of $\mathrm{Pb}$ from body stores, to a higher past or ongoing exposure to $\mathrm{Pb}$, or a combination of both. 
Table 5 Daily urinary metal excretion (in $\mu \mathrm{g} /$ day) according to season in pregnant women with or without preeclampsia in Kinshasa

\begin{tabular}{|c|c|c|c|c|c|c|c|}
\hline & \multicolumn{2}{|l|}{ Rainy season $(N=67)$} & \multicolumn{2}{|l|}{ Dry season $(N=109)$} & \multirow{2}{*}{$\begin{array}{l}P \text { for } \\
\text { group }^{\#}\end{array}$} & \multirow{2}{*}{$\begin{array}{l}P \text { for } \\
\text { season }\end{array}$} & \multirow{2}{*}{$\begin{array}{l}P \text { for } \\
\text { interaction }\end{array}$} \\
\hline & Control $(N=33)$ & Preeclamptic $(N=34)$ & Control $(N=55)$ & Preeclamptic $(N=54)$ & & & \\
\hline Diuresis (mL) & $1,225(910-1,600)$ & $916(680-1,100)$ & $1,156(950-1,350)$ & $901(720-1,100)$ & $<0 \cdot 001$ & $0 \cdot 38$ & 0.58 \\
\hline $\mathrm{Li}$ & $14 \cdot 3(11 \cdot 4-21 \cdot 6)^{c}$ & $7 \cdot 82(4 \cdot 25-12 \cdot 9)^{b}$ & $4 \cdot 75(3 \cdot 37-7 \cdot 03)^{a}$ & $5 \cdot 04(3 \cdot 47-7 \cdot 27)^{a}$ & $0 \cdot 005$ & $<0 \cdot 001$ & 0.003 \\
\hline $\mathrm{Al}$ & $144(69 \cdot 5-318)^{\mathrm{b}}$ & $261(71 \cdot 0-907)^{\mathrm{b}}$ & $38 \cdot 4(13 \cdot 1-103 \cdot 7)^{a}$ & $66 \cdot 1(23 \cdot 0-178)^{a}$ & 0.005 & $<0 \cdot 001$ & $0 \cdot 90$ \\
\hline V & $1 \cdot 62(0 \cdot 98-2 \cdot 89)^{a}$ & $1 \cdot 66(0 \cdot 90-3 \cdot 48)^{a}$ & $1 \cdot 65(1 \cdot 13-2 \cdot 48)^{\mathrm{a}}$ & $1 \cdot 86(1 \cdot 24-2 \cdot 90)^{\mathrm{a}}$ & 0.51 & 0.54 & 0.65 \\
\hline $\mathrm{Cr}$ & $1 \cdot 81(0 \cdot 63-4 \cdot 38)^{a, b}$ & $4 \cdot 36(1 \cdot 23-23 \cdot 8)^{b}$ & $0 \cdot 70(0 \cdot 19-1 \cdot 93)^{\mathrm{a}}$ & $3 \cdot 62(0 \cdot 70-19 \cdot 9)^{b}$ & $<0 \cdot 001$ & 0.038 & $0 \cdot 16$ \\
\hline $\mathrm{Mn}$ & $17 \cdot 5(4 \cdot 3-28 \cdot 1)^{a, b}$ & $26 \cdot 7(4 \cdot 13-110)^{a, b}$ & $7 \cdot 74(1 \cdot 10-29 \cdot 9)^{\mathrm{a}}$ & $47 \cdot 3(7 \cdot 63-527)^{\mathrm{b}}$ & $0 \cdot 007$ & 0.76 & 0.09 \\
\hline Co & $1 \cdot 10(0 \cdot 61-1 \cdot 90)^{\mathrm{b}}$ & $2 \cdot 30(0 \cdot 69-4 \cdot 53)^{\mathrm{b}}$ & $0 \cdot 43(0 \cdot 15-1 \cdot 21)^{\mathrm{a}}$ & $1 \cdot 49(0 \cdot 63-3 \cdot 78)^{b}$ & $<0.001$ & $<0.001$ & $0 \cdot 21$ \\
\hline $\mathrm{Ni}$ & $6 \cdot 55(3 \cdot 65-15 \cdot 1)^{a, b}$ & $19 \cdot 4(6 \cdot 26-90 \cdot 7)^{c}$ & $3 \cdot 87(1 \cdot 97-7 \cdot 44)^{\mathrm{a}}$ & $8 \cdot 59(4 \cdot 71-13 \cdot 0)^{b}$ & $<0 \cdot 001$ & $<0 \cdot 001$ & 0.42 \\
\hline $\mathrm{Cu}$ & $45 \cdot 9(16 \cdot 1-140)^{a}$ & $164(81 \cdot 2-425)^{b}$ & $35 \cdot 7(6 \cdot 5-186)^{a}$ & $213(53.9-757)^{b}$ & $<0 \cdot 001$ & 0.99 & $0 \cdot 33$ \\
\hline $\mathrm{Zn}$ & $807(362-1,053)^{a}$ & $5,220(1,391-10,898)^{b}$ & $663(143-1,107)^{a}$ & $4,856(535-50,760)^{b}$ & $<0.001$ & 0.71 & 0.86 \\
\hline As & $59 \cdot 9(39 \cdot 5-91 \cdot 8)^{c}$ & $49 \cdot 5(25 \cdot 3-86 \cdot 0)^{\mathrm{b}, \mathrm{c}}$ & $20 \cdot 4(13 \cdot 1-26 \cdot 7)^{a}$ & $35 \cdot 0(20 \cdot 5-60 \cdot 5)^{b}$ & $0 \cdot 18$ & $<0.001$ & 0.005 \\
\hline $\mathrm{Se}$ & $55 \cdot 4(42 \cdot 4-86 \cdot 7)^{b}$ & $41 \cdot 6(30 \cdot 3-77 \cdot 3)^{b}$ & $21 \cdot 9(12 \cdot 6-31 \cdot 0)^{\mathrm{a}}$ & $35 \cdot 9(19 \cdot 3-59 \cdot 7)^{\mathrm{b}}$ & $0 \cdot 14$ & $<0 \cdot 001$ & 0.005 \\
\hline Mo & $24 \cdot 3(14 \cdot 2-50 \cdot 7)^{b}$ & $17 \cdot 4(10 \cdot 0-37 \cdot 0)^{a, b}$ & $11 \cdot 4(6 \cdot 10-14 \cdot 4)^{\mathrm{a}}$ & $15 \cdot 7(7 \cdot 1-25 \cdot 8)^{a, b}$ & 0.97 & $0 \cdot 010$ & 0.051 \\
\hline $\mathrm{Cd}$ & $0.73(0.47-0.98)^{a}$ & $1 \cdot 62(0 \cdot 61-3 \cdot 27)^{\mathrm{b}}$ & $0.54(0 \cdot 29-0 \cdot 55)^{\mathrm{a}}$ & $1 \cdot 45(0 \cdot 59-2 \cdot 64)^{b}$ & $<0.001$ & $0 \cdot 30$ & 0.63 \\
\hline Sn & $1 \cdot 77(0 \cdot 78-6 \cdot 26)^{a}$ & $12 \cdot 2(4 \cdot 6-60 \cdot 2)^{b}$ & $1 \cdot 25(0 \cdot 44-2 \cdot 28)^{\mathrm{a}}$ & $7 \cdot 74(1 \cdot 35-24 \cdot 0)^{b}$ & $<0.001$ & $0 \cdot 20$ & 0.87 \\
\hline $\mathrm{Sb}$ & $2 \cdot 15(1 \cdot 34-3 \cdot 95)^{c}$ & $3 \cdot 22(1 \cdot 28-7 \cdot 80)^{c}$ & $0 \cdot 22(0 \cdot 13-0 \cdot 40)^{\mathrm{a}}$ & $1 \cdot 10(0 \cdot 35-3 \cdot 23)^{\mathrm{b}}$ & $<0 \cdot 001$ & $<0 \cdot 001$ & 0.004 \\
\hline $\mathrm{Te}$ & $0 \cdot 15(0 \cdot 13-0 \cdot 21)^{a, b}$ & $0 \cdot 11(0 \cdot 09-0 \cdot 18)^{a}$ & $0 \cdot 11(0 \cdot 06-0 \cdot 23)^{a}$ & $0 \cdot 27(0 \cdot 10-0 \cdot 38)^{\mathrm{b}}$ & $0 \cdot 10$ & $0 \cdot 11$ & 0.002 \\
\hline $\mathrm{Ba}$ & $14 \cdot 0(6 \cdot 3-26 \cdot 0)^{a, b}$ & $35 \cdot 5(7 \cdot 46-104)^{\mathrm{b}}$ & $13 \cdot 0(4 \cdot 7-30 \cdot 7)^{\mathrm{a}}$ & $26 \cdot 5(5 \cdot 4-91 \cdot 2)^{b}$ & 0.001 & $0 \cdot 44$ & 0.66 \\
\hline $\mathrm{Tl}$ & $0.42(0 \cdot 24-0 \cdot 73)^{b}$ & $0.33(0 \cdot 20-0 \cdot 62)^{\mathrm{b}}$ & $0 \cdot 20(0 \cdot 13-0 \cdot 35)^{\mathrm{a}}$ & $0 \cdot 29(0 \cdot 23-0 \cdot 46)^{b}$ & $0 \cdot 55$ & $<0 \cdot 001$ & $0 \cdot 010$ \\
\hline $\mathrm{Pb}$ & $17 \cdot 0(5 \cdot 5-36 \cdot 1)^{a, b}$ & $46 \cdot 3(6 \cdot 5-254)^{b}$ & $6 \cdot 24(2 \cdot 52-9 \cdot 94)^{\mathrm{a}}$ & $72 \cdot 4(9 \cdot 3-358)^{b}$ & $<0 \cdot 001$ & $0 \cdot 37$ & 0.019 \\
\hline U & $0 \cdot 12(0 \cdot 08-0 \cdot 27)^{c}$ & $0 \cdot 14(0 \cdot 08-0 \cdot 34)^{c}$ & $0.03(0 \cdot 02-0 \cdot 05)^{\mathrm{a}}$ & $0.05(0.02-0 \cdot 11)^{b}$ & 0.028 & $<0 \cdot 001$ & $0 \cdot 13$ \\
\hline
\end{tabular}

Data are geometric means $\left(25^{\text {th }}-75^{\text {th }}\right.$ percentile) of daily urinary excretion in $\mu \mathrm{g} /$ day

${ }^{\#} P$-values obtained by two-way ANOVA on log-transformed values ${ }^{a, b, c}$ Values with the same letter in superscript do not differ significantly from each other, according to Tukey's post-hoc test

Why $\mathrm{Pb}$ may be instrumental in causing preeclampsia has not been elucidated. Most authors have evoked the known nephrotoxicity and vascular endothelial toxicity of $\mathrm{Pb}[5]$. We did not evaluate whether the excretion of $\mathrm{Pb}$ (or any other element) correlated quantitatively with indices of severity (such as proteinuria or arterial pressure), but we did not find higher urinary metal values in the six women with full-blown eclampsia compared to those with preeclampsia only.

Other metals have not received as much attention as $\mathrm{Pb}$ in the context of preeclampsia. Because $\mathrm{Pb}$ and the other trace elements were highly correlated in urine, most metals were also increased among preeclamptic women. This could imply that "metal exposure" (as captured by our principal component analysis) is related to preeclampsia, with $\mathrm{Pb}$ being essentially a marker of risk rather than a causal agent. However, of all the measured toxic elements, $\mathrm{Pb}$ exhibited the strongest contrast between preeclampsia and no preeclampsia, although $\mathrm{Sn}$ and $\mathrm{Zn}$ also differed as much between the two groups.

Like $\mathrm{Pb}, \mathrm{Sn}$ is stored in bone but inorganic Sn compounds are not well absorbed and much less toxic than
$\mathrm{Pb}$ [32] and we found no studies investigating the relation between $\mathrm{Sn}$ and preeclampsia.

In contrast, various studies have investigated the possible implication of $\mathrm{Zn}, \mathrm{Se}, \mathrm{Cu}$, or $\mathrm{Mn}$ in preeclampsia because these trace metals are essential micronutrients involved in anti-oxidant defence [33-35]. Consequently, deficiencies in these essential elements, rather than excesses, are of concern. Accordingly, serum concentrations of $\mathrm{Zn}$ have been found to be decreased in preeclampsia [34]. Similarly, a low Se status has been implicated in reproductive and obstetric complications, including preeclampsia $[33,34,36]$. In contrast, serum $\mathrm{Cu}$ has been found to be decreased [37-40], unchanged [41] or increased [42-45] in preeclampsia. One study reported a decrease in $\mathrm{Mn}$ in umbilical blood from neonates born to mothers with preeclampsia [46]. In our study, preeclamptic women had markedly elevated urinary values for $\mathrm{Zn}, \mathrm{Cu}$ and $\mathrm{Mn}$, when compared with either the control group or upper reference limits. For Se, the differences between the two groups were less marked and the values were not particularly high compared to reference values [14]. In the absence of blood or serum concentrations of these essential metals, we cannot directly compare our findings with those of the literature. 


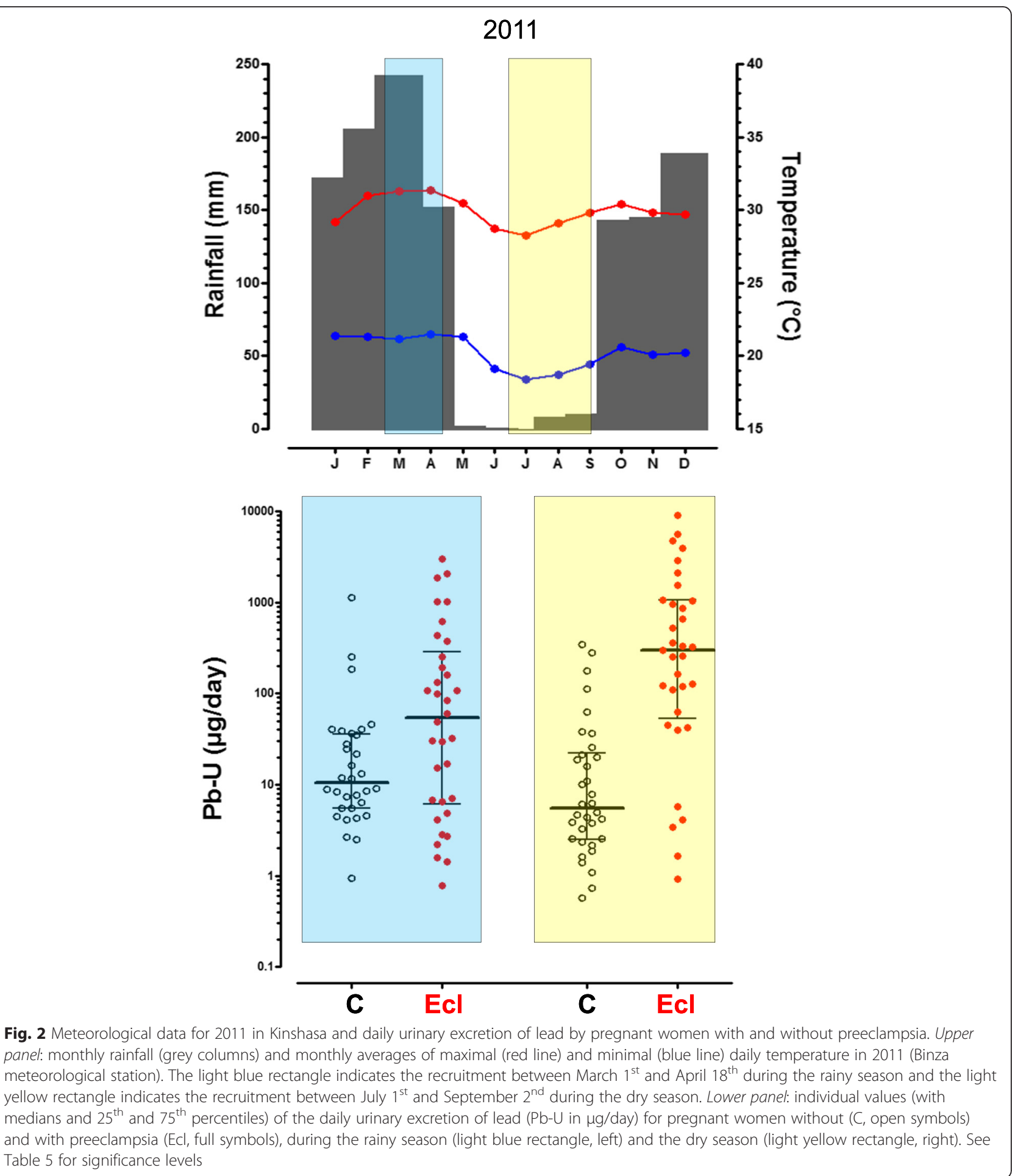

$\mathrm{Cd}$ excretion was 2.5 fold higher in preeclamptic women than in control women, possibly due to proteinuria, but we found almost no evidence for a role of $\mathrm{Cd}$ in the pathogenesis of preeclampsia [28]. The urinary values of As were not very high and the differences between the groups were not pronounced. Although As is vasculotoxic [47], As has not been associated with preeclampsia.

The incidence of preeclampsia in Kinshasa is twice as high in the dry season than in the rainy season [2]. A possible explanation is the lower availability and, hence, reduced consumption of fresh vegetables and fruit 
during the dry season, especially among disadvantaged people $[4,48]$. However, another feature of the dry season in countries with few hardened surfaces is a much higher aerial dust suspension than in the rainy season, thus leading to more pollutant exposure via the air and through contamination of food, clothes and indoor surfaces. Seasonal influences mediated by soil exposure have been well documented for $\mathrm{Pb}$, especially among young children in the USA [7, 49-52]. In pregnant women from Mexico City, blood $\mathrm{Pb}$ was higher during fall and winter (dry and cold) and lower during spring and summer (rainy) [53]. No seasonal effects were apparent for blood $\mathrm{Pb}$ in Australian children and women [54].

We observed significant seasonal differences for the urinary excretion of various metals but, against expectation, the daily excretion of metals was not highest during the dry season. Thus, in the control group, $\mathrm{Pb}$ tended to be higher in the rainy season $(14.4 \mu \mathrm{g} / \mathrm{L}$ and $17.0 \mu \mathrm{g} /$ day $)$ than in the dry season $(5.6 \mu \mathrm{g} / \mathrm{L}$ and $6.2 \mu \mathrm{g} /$ day). We have no explanations for this counterintuitive observation. We speculate that during pregnancy the urinary excretion of $\mathrm{Pb}$ (and other metals) is dominated by the amount that is being extracted from the skeletal stores and, hence, by the exposure of the previous months, rather than by ongoing exposure. Among women with preeclampsia, the urinary values were also not higher in the dry season than in the rainy season, but the seasonal differences tended to be less pronounced than in normal women. This led to significant or nearly significant interactions between group and season for several elements. For $\mathrm{Pb}$, the relative difference between cases and controls was much larger in the dry season than in the rainy season. Admittedly, the interpretation of these interactions with season is not straightforward, but the observed seasonal differences do suggest that metal exposure differs between seasons in Kinshasa. Whether and how this relates to the causal pathway with preeclampsia remains to be established by prospective studies, which should include assessments of environmental and dietary sources of exposure.

Indeed, we do not know the exact sources of toxic metals in our population. African geophagic soil samples may contain high levels of lead [55], but in our study the proportions of women reporting geophagy did not differ between preeclamptic women (32\%) and control women (27\%). High blood $\mathrm{Pb}$ levels in adults and children from urban Kinshasa have been attributed to leaded gasoline and informal car battery recycling in some residences [56]. We have some indications that the women with preeclampsia had more opportunities for exposure through artisanal activities, such as battery recycling, car painting or metal working close to their homes. The devastating effects of artisanal activities, such as recycling batteries or processing gold ore, for children in
African communities have been demonstrated in Senegal [57] and Nigeria [58].

\section{Conclusions}

Our study provides novel evidence for an excessive exposure to trace metals among pregnant women in a large African city, Kinshasa. The markedly increased urinary excretion of metals, especially $\mathrm{Pb}$, observed in preeclampsia may be related to the high incidence of preeclampsia in Kinshasa. An important public health issue is to ascertain the main sources of exposure to toxic metals in Kinshasa and to take preventive measures to avoid further contamination of pregnant women and children.

\section{Additional file}

Additional file 1: Toxic metals and preeclampsia in Kinshasa: additional data. (DOCX $85 \mathrm{~kb}$ )

\section{Abbreviations}

ANOVA: analysis of variance; BMI: body mass index; Cl: confidence interval; GM: geometric mean; ICP-MS: inductively coupled plasma mass

spectrometry; LOD: limit of detection; NHANES: national health and nutrition examination survey; OR: odds ratio; PC: principal component; PCA: principal component analysis.

\section{Competing interests}

The authors declare that they have no competing interests.

\section{Authors' contributions}

J.-P. Elongi conceived and designed the study, organized the data collection from patients and controls, performed most of the clinical work and collected most of the data, performed data entry, participated in data analysis and interpretation of findings, reviewed the literature, wrote the first and successive drafts of the article. H. Scheers participated in data entry, performed statistical analyses and participated in writing successive drafts of the article. V. Haufroid supervised the analysis of metals in his laboratory, contributed to the interpretation of findings and writing the article. B. Tandu-Umba participated in study design, supervised the research, contributed to the interpretation of findings and writing the article. B. Buassa contributed to the interpretation of findings and writing the article. F. Verdonck participated in study design, was instrumental in securing funds for travel and subsistence, contributed to the interpretation of findings and writing the article. B. Spitz conceived and designed the study, supervised the research, contributed to the interpretation of findings and writing the article. B. Nemery conceived and designed the study, participated in the interpretation of findings, reviewed the literature, wrote successive drafts and the final version of the article. All authors accept responsibility for the article. All authors read and approved the final manuscript.

\section{Acknowledgements}

The authors are grateful to Ms. Gladys Deumer for making the metal measurements and to the staff of the Hôpital Général de Kinshasa for their logistic support and they also thank the participants.

This study was not supported by any specific grant. It was part of the doctoral thesis of J.-P. Elongi Moyene, who gratefully acknowledges the financial support received from the ALUMNI of the Faculty of Medicine of the KU Leuven for his travel to and subsistence in Leuven during his doctoral research.

\section{Author details}

'Department of Gynecology and Obstetrics, University of Kinshasa, and General Hospital of Kinshasa, Kinshasa, Democratic Republic of Congo. ${ }^{2}$ Department of Public Health and Primary Care, Centre for Environment and Health, KU Leuven, Leuven, Belgium. ${ }^{3}$ Louvain centre for Toxicology and Applied Pharmacology, Institut de recherche expérimentale et clinique, 
Université catholique de Louvain, Brussels, Belgium. ${ }^{4}$ Faculty of Medicine, KU Leuven, Leuven, Belgium. ${ }^{5}$ Department of Development and Regeneration (Pregnancy, Foetus and Newborn), KU Leuven, Leuven, Belgium. ${ }^{6}$ Division of Gynecology and Obstetrics, UZ Leuven, Leuven, Belgium. ${ }^{7}$ Hôpital Général de Kinshasa, Avenue de l'Hôpital, Commune de la Gombe, Kinshasa, DR, Congo.

Received: 29 July 2015 Accepted: 24 March 2016

Published online: 05 April 2016

\section{References}

1. Sibai B, Dekker G, Kupferminc M. Pre-eclampsia. Lancet. 2005;365:785-99.

2. Elongi JP, Tandu B, Spitz B, Verdonck F. Influence de la variation saisonnière sur la prévalence de la pré-éclampsie à Kinshasa [Influence of the seasonal variation on the prevalence of pre-eclampsia in Kinshasa]. Gynecol Obstet Fertil. 2011;39:132-5.

3. Roberts JM, Cooper DW. Pathogenesis and genetics of pre-eclampsia. Lancet. 2001;357:53-6.

4. Elongi JP, Bamba D, Tandu U, Spitz B, Verdonck F, Dikamba N. Appréciation de la consommation des légumes verts et fruits chez les gestantes à Kinshasa [Estimated consumption of green vegetables and fruit among pregnant women in Kinshasa]. Médecine d'Afrique noire 2011; $N^{\circ}$ 5803:115-121.

5. Kennedy DA, Woodland C, Koren G. Lead exposure, gestational hypertension and pre-eclampsia: a systematic review of cause and effect. J Obstet Gynaecol. 2012;32:512-7.

6. Tuakuila J, Lison D, Lantin AC, Mbuyi F, Deumer G, Haufroid V, et al. Worrying exposure to trace elements in the population of Kinshasa, Democratic Republic of Congo (DRC). Int Arch Occup Environ Health. 2012;85:927-39.

7. Laidlaw MA, Mielke HW, Filippelli GM, Johnson DL, Gonzales CR. Seasonality and children's blood lead levels: developing a predictive model using climatic variables and blood lead data from Indianapolis, Indiana, Syracuse, New York, and New Orleans, Louisiana (USA). Environ Health Perspect. 2005; 113:793-800.

8. Lindheimer MD, Roberts JM, Cunningham FG, Chesley L. Introduction, History, Controversies, and Definitions. In: Lindheimer MD, Roberts JM, Cunningham FG, editors. Chesley's hypertensive disorders in pregnancy. San Diego, CA; Burlington, MA; London: Academic Press-Elsevier; 2009. p. 1-23.

9. Njiru $H$, Elchalal U, Paltiel O. Geophagy during pregnancy in Africa: a literature review. Obstet Gynecol Surv. 2011;66:452-9.

10. Banza CL, Nawrot TS, Haufroid V, Decrée S, De Putter T, Smolders E, et al. High human exposure to cobalt and other metals in Katanga, a mining area of the Democratic Republic of Congo. Environ Res. 2009;109:745-52.

11. Sughis M, Nawrot TS, Riaz A, Ikram-Dar U, Mahmood A, Haufroid V, et al. Metal exposure in schoolchildren and working children. A urinary biomonitoring study from Lahore, Pakistan. Int J Hyg Environ Health. 2014; 217:669-77.

12. Benjamini $Y$, Hochberg $Y$. Controlling the false discovery rate: a practical and powerful approach to multiple testing. J R Stat Soc B. 1995;57:289-300.

13. Paschal DC, Ting BG, Morrow JC, Pirkle JL, Jackson RJ, Sampson EJ, et al. Trace metals in urine of United States residents: reference range concentrations. Environ Res. 1998;76:53-9.

14. Komaromy-Hiller G, Ash KO, Costa R, Howerton K. Comparison of representative ranges based on U.S. patient population and literature reference intervals for urinary trace elements. Clin Chim Acta. 2000;296:71-90.

15. Hoet $P$, Jacquerye $C$, Deumer $G$, Lison D, Haufroid V. Reference values and upper reference limits for 26 trace elements in the urine of adults living in Belgium. Clin Chem Lab Med. 2013;51:839-49.

16. Silbergeld EK. Lead in bone: implications for toxicology during pregnancy and lactation. Environ Health Perspect. 1991;91:63-70.

17. Hertz-Picciotto I, Schramm M, Watt-Morse M, Chantala K, Anderson J, Osterloh J. Patterns and determinants of blood lead during pregnancy. Am J Epidemiol. 2000;152:829-37.

18. Gulson BL, Mizon KJ, Korsch MJ, Palmer JM, Donnelly JB. Mobilization of lead from human bone tissue during pregnancy and lactation-a summary of long-term research. Sci Total Environ. 2003;303:79-104

19. Gulson BL, Mizon KJ, Palmer JM, Korsch MJ, Donnelly JB. Urinary excretion of lead during pregnancy and postpartum. Sci Total Environ. 2000;262:49-55.

20. Adekunle IM, Ogundele JA, Oguntoke O, Akinloye OA. Assessment of blood and urine lead levels of some pregnant women residing in Lagos, Nigeria. Environ Monit Assess. 2010;170:467-74.
21. Apostoli P, Telisman S, Sager PS. Reproductive and developmental toxicity of metals. In: Nordberg GF, Fowler BA, Nordberg M, Friberg LT, editors. Handbook on the toxicology of metals. 3rd ed. Amsterdam: Academic Press - Elsevier; 2007. p. 214-9.

22. Lauwerys R, Hoet P. Industrial Chemical Exposure. Guidelines for Biological Monitoring. 3rd ed. Boca Raton, FL: Lewis; 2001.

23. Cocker J, Mason HJ, Warren ND, Cotton RJ. Creatinine adjustment of biological monitoring results. Occup Med (Lond). 2011;61:349-53.

24. Karumanchi SA, Maynard SE, Stillman IE, Epstein FH, Sukhatme VP. Preeclampsia: a renal perspective. Kidney Int. 2005;67:2101-13.

25. Lafayette RA, Druzin M, Sibley R, Derby G, Malik T, Huie P, et al. Nature of glomerular dysfunction in pre-eclampsia. Kidney Int. 1998;54:1240-9.

26. Troesken W. Lead exposure and eclampsia in Britain, 1883-1934. Environ Res. 2006;101:395-400

27. Chen XK, Yang Q, Smith G, Krewski D, Walker M, Wen SW. Environmental lead level and pregnancy-induced hypertension. Environ Res. 2006; 100:424-30.

28. Vigeh M, Yokoyama K, Ramezanzadeh F, Dahaghin M, Sakai T, Morita Y, et al. Lead and other trace metals in preeclampsia: a case-control study in Tehran, Iran. Environ Res. 2006;100:268-75.

29. Ikechukwu IC, Ojareva OI, Ibhagbemien AJ, Okhoaretor OF, Oluwatomi OB, Akhalufo OS, et al. Blood lead, calcium, and phosphorus in women with preeclampsia in Edo State, Nigeria. Arch Environ Occup Health. 2012;67:163-9.

30. Motawei SM, Attalla SM, Gouda HE, El-Harouny MA, El-Mansoury AM. Lead level in pregnant women suffering from pre-eclampsia in Dakahlia, Egypt. Int J Occup Environ Med. 2013;4:36-44.

31. Zahran S, Magzamen S, Breunig IM, Mielke HW. Maternal exposure to neighborhood soil Pb and eclampsia risk in New Orleans, Louisiana (USA): Evidence from a natural experiment in flooding. Environ Res. 2014;133:274-81.

32. Ostrakhovitch EA, Cherian MG. Tin. In: Nordberg GF, Fowler BA, Nordberg M Friberg LT, editors. Handbook on the toxicology of metals. 3rd ed. Amsterdam: Academic Press - Elsevier; 2007. p. 839-59.

33. Mistry HD, Broughton PF, Redman CW, Poston L. Selenium in reproductive health. Am J Obstet Gynecol. 2012;206:21-30.

34. Mistry HD, Williams PJ. The importance of antioxidant micronutrients in pregnancy. Oxid Med Cell Longev. 2011;2011:841749.

35. Hovdenak N, Haram K. Influence of mineral and vitamin supplements on pregnancy outcome. Eur J Obstet Gynecol Reprod Biol. 2012;164:127-32.

36. Mariath AB, Bergamaschi DP, Rondo PH, Tanaka AC, Hinnig PF, Abbade JF, et al. The possible role of selenium status in adverse pregnancy outcomes. Br J Nutr. 2011;105:1418-28.

37. Kumru S, Aydin S, Simsek M, Sahin K, Yaman M, Ay G. Comparison of serum copper, zinc, calcium, and magnesium levels in preeclamptic and healthy pregnant women. Biol Trace Elem Res. 2003;94:105-12.

38. Acikgoz S, Harma M, Harma M, Mungan G, Can M, Demirtas S. Comparison of angiotensin-converting enzyme, malonaldehyde, zinc, and copper levels in preeclampsia. Biol Trace Elem Res. 2006:113:1-8.

39. Negi R, Pande D, Karki K, Kumar A, Khanna RS, Khanna HD. Trace elements and antioxidant enzymes associated with oxidative stress in the pre-eclamptic/ eclamptic mothers during fetal circulation. Clin Nutr. 2012;31:946-50.

40. Al-Jameil N, Tabassum H, Al-Mayouf H, Aljohar Hl, Alenzi ND, Hijazy SM, et al. Analysis of serum trace elements-copper, manganese and zinc in preeclamptic pregnant women by inductively coupled plasma optical emission spectrometry: a prospective case controlled study in Riyadh, Saudi Arabia. Int J Clin Exp Pathol. 2014:7:1900-10.

41. Farzin L, Sajadi F. Comparison of serum trace element levels in patients with or without pre-eclampsia. J Res Med Sci. 2012;17:938-41.

42. Ilhan N, Ithan N, Simsek M. The changes of trace elements, malondialdehyde levels and superoxide dismutase activities in pregnancy with or without preeclampsia. Clin Biochem. 2002;35:393-7.

43. Atamer $Y$, Kocyigit $Y$, Yokus B, Atamer A, Erden AC. Lipid peroxidation, antioxidant defense, status of trace metals and leptin levels in preeclampsia. Eur J Obstet Gynecol Reprod Biol. 2005;119:60-6.

44. Serdar Z, Gur E, Develioglu O. Serum iron and copper status and oxidative stress in severe and mild preeclampsia. Cell Biochem Funct. 2006;24:209-15.

45. Ranjkesh F, Jaliseh HK, Abutorabi S. Monitoring the copper content of serum and urine in pregnancies complicated by preeclampsia. Biol Trace Elem Res. 2011;144:58-62.

46. Jones EA, Wright JM, Rice G, Buckley BT, Magsumbol MS, Barr DB, et al. Metal exposures in an inner-city neonatal population. Environ Int. 2010;36:649-54. 
47. Fowler BA, Chou SJ, Jones RL, Chen C-J. Arsenic. In: Nordberg GF, Fowler BA, Nordberg M, Friberg LT, editors. Handbook on the toxicology of metals. 3rd ed. Amsterdam: Academic Press - Elsevier; 2007. p. 367-406.

48. Longo-Mbenza B, Tshimanga KB, Buassa-bu-Tsumbu B, Kabangu MJ. Diets rich in vegetables and physical activity are associated with a decreased risk of pregnancy induced hypertension among rural women from Kimpese, DR Congo. Niger J Med. 2008;17:265-9.

49. Mielke HW, Gonzales CR, Smith MK, Mielke PW. The urban environment and children's health: soils as an integrator of lead, zinc, and cadmium in New Orleans, Louisiana. USA Environ Res. 1999;81:117-29.

50. Mielke HW, Laidlaw MA, Gonzales CR. Estimation of leaded (Pb) gasoline's continuing material and health impacts on 90 US urbanized areas. Environ Int. 2011;37:248-57.

51. Laidlaw MA, Zahran S, Mielke HW, Taylor MP, Filippelli GM. Re-suspension of lead contaminated urban soil as a dominant source of atmospheric lead in Birmingham, Chicago, Detroit and Pittsburgh. Atmos Environ. 2011;49:302-10.

52. Zahran S, Laidlaw MA, McElmurry SP, Filippelli GM, Taylor M. Linking source and effect: resuspended soil lead, air lead, and children's blood lead levels in Detroit, Michigan. Environ Sci Technol. 2013;47:2839-45.

53. Farias P, Borja-Aburto VH, Rios C, Hertz-Picciotto I, Rojas-Lopez M, Chavez-Ayala R. Blood lead levels in pregnant women of high and low socioeconomic status in Mexico City. Environ Health Perspect. 1996;104:1070-4.

54. Gulson BL, Mizon KJ, Korsch MJ, Mahaffey KR, Pederson D. Limited seasonality effects on blood lead for a small cohort of female adults and children. Sci Tota Environ. 2000;253:119-26.

55. Kutalek R, Wewalka G, Gundacker C, Auer H, Wilson J, Haluza D, et al. Geophagy and potential health implications: geohelminths, microbes and heavy metals. Trans R Soc Trop Med Hyg. 2010;104:787-95.

56. Tuakuila J, Lison D, Mbuyi F, Haufroid V, Hoet P. Elevated blood lead levels and sources of exposure in the population of Kinshasa, the capital of the Democratic Republic of Congo. J Expo Sci Environ Epidemiol. 2013;23:81-7.

57. Haefliger P, Mathieu-Nolf M, Lociciro S, Ndiaye C, Coly M, Diouf A, et al. Mass lead intoxication from informal used lead-acid battery recycling in Dakar, Senegal. Environ Health Perspect. 2009;117:1535-40.

58. Dooyema CA, Neri A, Lo YC, Durant J, Dargan Pl, Swarthout T, et al Outbreak of fatal childhood lead poisoning related to artisanal gold mining in northwestern Nigeria, 2010. Environ Health Perspect. 2012;120:601-7.

\section{Submit your next manuscript to BioMed Centra and we will help you at every step:}

- We accept pre-submission inquiries

- Our selector tool helps you to find the most relevant journal

- We provide round the clock customer support

- Convenient online submission

- Thorough peer review

- Inclusion in PubMed and all major indexing services

- Maximum visibility for your research

Submit your manuscript at www.biomedcentral.com/submit

) Biomed Central 